\title{
MORE THAN "A LURE TO THE GILDED BOWER OF MATRIMONY": THE EDUCATION OF METHODIST WOMEN MISSIONARIES, 1881-1925
}

\author{
Rosemary R. Gagan
}

For nearly a half century, from its inception in 1881 until 1925 when its mandate was subsumed by the creation of the United Church of Canada, the Woman's Missionary Society (W.M.S.) of the Methodist Church of Canada energetically promoted its church's gospel of individual salvation and moral and social reform in its far-flung mission fields in Japan, West China, and in Canada's frontier settlements and inner-city ghettos. Vigorous as the W.M.S.'s spiritual commission was, throughout its history, the Society was even more effectual as a social agency which touched the lives of thousands of women in Canada and abroad. Its Canadian lay members, the women to whom the Society ministered, and the missionaries it employed to advance the W.M.S. cause at home and abroad were all affected, some more beneficially than others, by their association with the W.M.S.

As participants in a national association dedicated to the salvation and rescue of women and children in Canada and the Orient, the membership of the vast network of W.M.S. auxiliaries gradually gained some understanding of and influence among women from unfamiliar cultures. Canadian women thus expanded their own limited perspectives to develop a less ethnocentric, and more altruistic, approach towards overseas missionary work. At the same time, women in both urban and rural communities grasped the opportunity to acquire the business, administrative, and public-speaking skills which, arguably, laid the essential groundwork to forge a more extensive and forceful women's movement directed to social and political goals.

Immigrant and native women in Canada became the recipients of the Society's well-intentioned, if sometimes misdirected, spiritual and material largess. In the Orient, women and girls welcomed the tangible advantages of modem medical treatment and education and the more elusive benefits identified with the self-esteem which the W.M.S. missionaries tried to encourage among dependent women in these feudal patriarchal societies where foot binding, arranged marriages, slavery, concubinage, female infanticide, and other forms of discrimination against women were still commonplace.

Equally important, within the context of Canadian women's history, the W.M.S., in its capacity as an employer, afforded a unique career opportunity for the more than 300 Canadian women whom it engaged between 1881 and 1925 as missionaries to execute its ambitious missionary programmes in Canada and overseas. The Society became a flexible vehicle which allowed educated, single middle-class women to join the minority of Canadian women of their day who deliberately sought professional careers at a time when the domestic imperative 
was not easily challenged and when female employment outside the home was still largely the province of single working aclass women.

The formal recruitment policies defined by the W.M.S. appealed particularly to educated single women from the small towns of Ontario and the Maritimes for whom employment as W.M.S. missionaries offered an attractive, respectable, and exciting altemative to domesticity, on the one hand, and to the restricted professional opportunities for women in secular careers, on the other. Daughters of the parsonage and of the mercantile and professional classes, often with several years of previous experience in the work-force - most frequently as teachers, but also as nurses, doctors, and church workers-and at an age beyond which marriage was a statistically receding expectation, were especially aturacted by the Society's appeals for workers in Christ's vineyards. However, as the following analysis illustrates, if all W.M.S. missionary recruits appear initially to have possessed the same deep commitment to serving God and their fellows, they were not equally successful or satisfied in their chosen vocation. The pattern of distinct social and educational differentials among the recruits contributed, partly by intent and partly through circumstances unique to a particular mission field, to the emergence of a hierarchical division of labour within W.M.S. missionary work which inevitably consigned the least capable and least experienced candidates to work among Canada's native people and immigrants, and the most accomplished, both socially and intellectually, to the politically more visible overseas mission fields, especially Japan. In the long run, these disparities help to explain why some women became career professionals, continuing with the Society until death or retirement, some for thirty to forty years, while for others, their single term with the W.M.S. merely bridged the years between dependence on parents and the establishment of their own households.

It has been possible, utilizing a variety of sources, to reconstruct for each of the W.M.S. missionaries a biographical profile which consists of date and place of birth, parental occupation, educational background, professional training, and work experience, and from this data to examine the women's collective characteristics. What follows is an analysis of the backgrounds, and in particular, the secular education and professional training, of a select group of women. Among other things, this analysis offers evidence about the characteristics common to a group of purposeful women who deliberately eschewed marriage and domesticity for the sake of a professional career. Moreover, an examination of their education and professional training elucidates the relationship between their apparent qualifications and the work-related opportunities available to them at the time to define and to control the quality of their professional lives, especially the degree of independence they sought, and partially realized, in a society and, more particularly, a hierarchical institution traditionally controlled by men.

From its inception, the Society's all-female Board of Managers, which also acted as the candidate selection committee, had a fixed notion about the appropriate qualifications and attributes for W.M.S. workers. It chose the missionaries painstakingly, considering their age, health, educational background, 
work-related experience, and, of course, their spiritual dedication. The Board may have advertised publicly in the Christian Guardian and the Missionary Outlook for its candidates, but this broad appeal did not mean that any woman activated by missionary zeal was necessarily endorsed by the Society. To deter obviously unqualified and otherwise unsuitable applicants or women who might merely be seeking adventure or avoiding personal responsibilities from even applying, and at the same time to ensure the desired homogeneity among their workers, the Society established explicit guidelines concerning the education, experience, age, marital status, and moral character of its prospective agents. This directive was published in the Society's Annual Report where any woman contemplating a missionary career could study it. Even when there were severe shortages of recruits to fill vacancies left by unforeseen resignations, the Board rejected applicants who did not conform to W.M.S. criteria.

Given the disposition of the job, it is not unexpected that the matter of Christian duty and dedication headed the list of requirements. First and foremost, a candidate "must believe herself divinely called to the work of a foreign missionary, and assert her belief that she is activated only by a desire to work in accordance with God's will." As evidence of her competence to function effectively in a foreign field, the Board requested proof of "Christian usefulness at home," usually verification from the woman's minister of her valuable contribution to church life. A few years later, a more explicit challenge to the intensity of the candidate's spiritual devotion appeared with the question, "Do you trust that you are inwardly moved by the Holy Ghost to take upon you the work of a foreign missionary?" No serious candidate would have answered negatively. Similarly, "Yes" was the only defensible response to the question of whether a recruit had "an experimental knowledge of salvation through the atonement of Jesus Christ our Lord"2 as irrefutable confirmation of the personal experience of conversion which persisted as a fundamental component of late nineteenth-century Canadian Methodism. ${ }^{3}$ The regulations went on to caution potential candidates that, if chosen, the Society assumed missionary work would be "the service of [their] effective years." They were required to "agree to give at least five of these years of continuous service, as a single woman, to the work of the Woman's Missionary Society, unless prevented by ill health." 4 To discourage impulsive or frivolous decisions, women who defaulted on the terms of their initial contract or resigned on grounds other than illness before completing the first term were obliged to repay a large portion, possibly all, of their outfitting and travel expenses. This was no trivial consideration because, for a missionary in the Orient, these costs could equal a year's wages.

To maximize the W.M.S. employees' potential and to try to guarantee some degree of maturity among the missionaries, the guidelines also specified age limits for the recruits. At first, the Society accepted women aged twenty-two to thirty, and some women over thirty who exhibited "a thorough, intellectual training, with a facility in languages, and a remarkable ability for Christian work." In actuality, more than $25 \%$ of all the missionaries and 46 of the 140 
home missionaries were at least 30 by the time they were hired, while 14 women $(10 \%)$ were 40 or older. Given a choice, the Board of Managers preferred mature women to younger, less-seasoned recruits, however eager and energetic. After 1895 , in response to serious internal problems in the Methodist Japan mission which jeopardized the Society's operations there, the Board and the senior staff in Japan concluded that some of the youngest women had been unable to manage their taxing responsibilities or to retaliate when the male General Board missionaries had tried to intimidate and coerce them. Consequently, the minimum age for W.M.S. missionaries was raised to twenty-five, allowing candidates three more years to prepare for their assignments. ${ }^{6}$

Finally, candidates were required to reply to questions about their education: whether they had studied Latin or modern languages, their degree of "proficien$c y$ " in languages, and whether they "readily acquire[d] the same." The Board also demanded "satisfactory testimonials in regard to scholarship," with proof of teaching experience or a knowledge of medicine and nursing, and, finally, a medical certificate confirming a recruit's physical fitness for the hardships which might lie ahead. ${ }^{8}$ From time to time, changes were implemented in the wording of the stipulations, but these central requirements applied throughout the Society's history. Generally, they served the Society's needs very well. In sum, the W.M.S. demanded, as its representatives, clever, experienced, and devout women, able, as Elizabeth Strachan, the Society's veteran Corresponding Secretary put it, to introduce the women of the world to the "Friend that sticketh closer than a brother" and to "purify the home fountain, from which it is hoped will flow clearer and sweeter streams into social, commercial and religious life." The demographic, social, educational, and religious profile of the women who were selected as W.M.S. missionaries seems to substantiate the Society's success in attracting, in the flesh, its missionary prototype.

Among the several attributes which distinguished the W.M.S. missionaries from the majority of Canadian women of the time, their high levels of education and their professional credentials seem the most exceptional. Whether or not Canadian Methodist women generally were better educated than women of other religious denominations cannot be confirmed on the basis of existing scholarship. Methodists were, however, among the first Protestant denominations in Canada to demonstrate concern about the availability and quality of education beyond the elementary level for women. The opening of Upper Canada Academy in 1836 initiated the Methodist Church's drive to educate its young women, although, ironically, when the school was taken over by Egerton Ryerson in 1841, women were no longer admitted. ${ }^{10}$ Nonetheless, by the last quarter of the nineteenth century, higher education for women had become "a very respectable cause" among Methodists. " In particular, Methodist spokesmen advocated a good education for women to strengthen their virtuous authority as wives and mothers, and to extend their influence as patrons of public philanthropy and guardians of individual and national morality as a remedy for the proliferation of social problems confronting Canada and the world. Prominent Methodist clergy and 
laity boasted about their church's enlightened and liberal attitudes towards women. But their open-mindedness was invariably tempered by the firmly fixed notion that the education and employment of women must continue to sustain them in their "separate spheres" to preserve traditional family and national values, and to uphold women's nurturing role. For example, in 1882, Rev. C. Payne asserted, rather pompously, in the Canadian Methodist Magazine, that "no religious body ever honoured woman as Methodism has done, and none ever enjoyed so richly the fruits of her peculiar endowments." 12 In 1888 , in a solicitation for "intelligent women" to become religious workers, teachers, and missionaries for the Methodist Church, the Christian Guardian argued that women needed to be educated for these admirable positions. But, reflecting the patriarchal nature of the church of the day which calculated women's value primarily in relation to the family's requirements, the Guardian insisted that women ought also to be educated as "intelligent companions of their husbands, and wise and capable teachers of their children."13

On the other hand, Rev. Benjamin Austin, the first principal of Alma College, a man with an understandable bias toward the education and employment of women, contended that woman's sphere was not nearly so limited as was commonly supposed. ${ }^{14}$ The census of 1881 had recorded 227 occupations employing women, and although he condemned cheap labour, Austin defended a woman's right to earn a living in even the most conventional male trades"milking a cow, making a horseshoe or packing shingles." 15 "No young woman," according to Austin, "should be placed in circumstances such as to make marriage an only refuge from poverty or dependence on her friends, or from a life of ennui." 16 The editor of the Methodist Magazine, William Withrow, agreed that education should provide women with some degree of independence and choice about their futures. He

repudiate[d] the idea so commonly entertained that the higher education of woman is only a lure to the gilded bower of matrimony, to enable her to make her market in life to win a prize in the lottery of marriage. It has loftier and sublimer ends than these-the development of the noblest part of her nature,the intellect and the affections; the expansion and culture of all her powers. ${ }^{17}$

Yet in spite of this eloquent verbiage, until at least World War I, even the best-educated and most determined Canadian women faced the harsh reality of sexual discrimination in their drive for educational and professional equality. They continued, consequently, to gravitate to occupations which society had designated as the special preserve of women.

Becoming a missionary was not, initially, such an established female career. Until the mid-nineteenth century, full-time paid missionary work had been a male bastion which women infiltrated only very slowly in the face of intense public sentiment against single women venturing alone to isolated areas, especially in 
Africa and the Orient. Until the founding of the W.M.S., Canadian Methodist missionary work was similarly a male preserve where missionaries' wives might serve as unpaid and usually unacknowledged helpmates if they chose. Given the circumstances and the lack of any precedent for professional women workers within the Methodist church, the W.M.S. was fortunate in being able to attract, from the outset, young middle-class women whose interest in an education for a career had so well equipped them for the challenge of missionary work.

Only one woman among the 190 W.M.S. missionaries for whom there is adequate educational data had not completed an elementary education when she applied to the Society. Because of her deficiency, the Board of Managers rejected Myrtle Armstrong as a candidate until she improved her educational qualifications. Four years as a secretary for the Toronto Bible College, during which Armstrong earned a diploma in stenography and bookkeeping from a Toronto technical school, assured the Board that she was competent to be assigned to work among eastern European immigrant groups in northern Alberta. ${ }^{18}$

High school attendance for girls was less routine than their enrolment at an elementary school, especially in the 1870 s and 1880 s when high schools or continuation schools were still located only in the larger towns and cities, where, in some instances, restrictive tuition fees were charged for high school instruction. ${ }^{19}$ Yet, with the exception of Armstrong, the W.M.S. recruits in the sample appear uniformly to have attended a secondary school, albeit some just long enough to obtain the minimum matriculation needed to register at a provincial normal school or a model school as preparation for a teaching career, while others remained until graduation. The proliferation of provincial diplomas and certificates, however, makes it impossible to determine exactly how many women actually graduated from a high school.

Most of the women remained close to home for their high school education, but at least 33 women (17\%) in the sample left their families to attend one of the several Methodist ladies' colleges established by the last decades of the nineteenth century to provide a suitable education for the daughters of the middle and upper classes. This, of course, is a comment on the social background of these women. Some, like Agnes Wintemute, enrolled at Alma College (which had opened in her home town of St. Thomas, Ontario, under the auspices of the Methodist Episcopal Church in 1881). ${ }^{20}$ Several young women (or their parents) chose another Methodist Episcopal school, Alexandra College, the women's affiliate of Albert College originally founded as the Belleville Seminary in $1857,{ }^{21}$ or Ontario Ladies' College which opened in 1874 in Whitby, or the older Hamilton Ladies' College (founded in 1858) until it closed in 1897.22 One in five (12 of 64) of the Maritime recruits attended Mount Allison in Sackville, New Brunswick, for at least a term.

Most Methodist ladies' colleges offered the choice of two three-year programmes at the high school level, both leading to the senior matriculation. One course, which emphasized English, classical studies, and foreign languages, led to the Mistress of Liberal Arts degree, ${ }^{23}$ while the less-exacting Mistress of 
English Language syllabus required advanced work in English but no other languages. ${ }^{24}$ In 1886 , nine years after women were first admitted to Victoria University, in Cobourg, Methodist ladies' colleges in Ontario became affiliates of that university. Some courses at the colleges were then approved for credit towards a B.A., ${ }^{25}$ but the practice appears to have been abandoned in 1921 when the Massey Foundation Commission to investigate the curriculum of Canadian Methodist colleges concluded that this policy discouraged women from pursuing a university degree. ${ }^{26}$ By 1920 , Alma College at least had become more versatile, if no less exclusive, offering in addition to preparation for high school and the high school curriculum, instruction in music, commerce, art, elocution, and household science.

Women at Methodist schools had, in addition to their academic studies, regular religious obligations to fulfill: daily chapel attendance, mealtime devotions, and prayers and church on Sunday. ${ }^{27}$ And, if Alma College was typical, the colleges were frequently visited by missionaries of both sexes carrying out their furlough obligations which required them to publicize their work for at least three months of their year's leave. Moreover, after 1908, both Alma and the Ontario Ladies' College hosted Methodist Church summer schools which were attended and taught by Methodist missionaries. ${ }^{28}$ Consequently, the atmosphere at these institutions, which, like their British counterparts, exuded "a strong reforming ethos," ${ }^{29}$ was likely to generate and sustain more than a passing interest in a future carcer as a missionary, while the exclusively female milieu of ladies' colleges bred a sense of gender solidarity, an asset which later sustained the women missionaries' autonomy, especially against the male assaults on their jurisdiction in overseas missions.

Those candidates who attended ladies' colleges belonged to a privileged group. The fees alone ensured that students were drawn from the prosperous upper and middle classes. In 1890, Alma College advertised costs of $\$ 190.00$ for four terms to cover board, room, lights, fuel, laundry, instruction in music and drawing, and calisthenics. If desired, riding lessons could be arranged at an additional $\$ 15.00$ for twelve sessions. According to Principal Austin, Alma's fees were the lowest in the country for a comparable education. ${ }^{30}$ Nonetheless, this kind of instruction for his daughters was quite beyond the means of, for example, a carpenter whose hourly wage in $190 \mathrm{l}$ was about twentywive cents. ${ }^{31}$ Even the fourteen daughters of clergymen among the W.M.S. missionaries probably attended ladies' colleges only because their fathers received a $50 \%$ fee reduction. The elitism of these institutions became the target of biting criticism. Mount Allison Ladies' College, in particular, was denounced at the end of the nineteenth century as a "finishing school for the children of wealthy families," where the girls' clothing was increasingly elaborate and ostentatious. ${ }^{32}$ Using parental occupational data from 1903 to 1908, John Reid has demonstrated what the fee schedules at these schools implied: women at Mount Allison may have come from varied backgrounds, but children of labourers were in a distinct 
minority. ${ }^{33}$ Similar statistics available for the parents of the future W.M.S. missionaries enrolled at ladies' colleges confirm Reid's conclusion.

For $65 \%$ of the women in the sample, attendance at high school, with or without graduating, marked the end of their formal education. Almost $70 \%$ of the women who did not continue to university began immediately to provide for their future by registering at a normal school, while another $9 \%$ entered nursing schools. The others whose backgrounds can be documented attended various business colleges and Bible institutes in Canada and the United States to receive specific training directed at a missionary career. On the other hand, one in three women in the sample continued her formal education at university. Although the insufficient data pertinent to the educational levels of Canadian women make meaningful statistical comparisons difficult, it is interesting to note that in 1941, a year when most of the W.M.S. missionaries were still alive to have been counted, only $6 \%$ of Canada's female population reported some university as their highest level of education. ${ }^{34}$ Clearly, the W.M.S. attracted a disproportionate share of Victorian Canada's most-educated women.

The superior educational standing of the W.M.S. missionaries as a group is probably associated with another of their shared characteristics, that is, their overwhelmingly middle-class social background. That so many of the future missionaries had middle-class origins is hardly surprising within the context of late nineteenth and early twentieth-century Canadian Methodism. The women's backgrounds coincide, if not with the reality, at least with the prevailing self-conception of the Canadian Methodist Church of the day, which envisaged itself as an institution sustained by a growing and prosperous middle class, and which hoped to accommodate many of the nouveau riche as a part of the larger constituency the church needed to pursue its ambitious designs for expansion at home and abroad. ${ }^{35}$ An examination of W.M.S. parental occupational data, compiled from census and W.M.S. records (available for 120 of the women-a smaller sample than for some other characteristics because occupational details were difficult to locate) reveals that $25(21 \%)$ of the fathers were farmers and 6 $(5 \%)$ had other agricultural occupations (for example, miller, sawyer, and stockdealer); $16(13 \%)$ engaged in business or commerce as merchants and manufacturers; 9 (7.5\%) can be categorized, rather loosely, as tradesmen: carpenters, butchers, and tailors. Three $(2.5 \%)$ had retired. Only 2 fathers $(2 \%)$ were reported as labourers. The other half (59) were professionals-physicians, teachers, and, above all else, ministers. ${ }^{36}$ In fact, $54(45 \%)$ fathers were either ordained ministers or, less commonly, missionaries. One in six of all W.M.S. missionaries was raised as "a daughter of the parsonage," while at least another $10 \%$ had one or more close relatives (grandfather, uncle, brother, sister) who were ministers or missionaries. More significantly, one in three women stationed in Japan was a minister's daughter, while half were related to members of the clergy, a factor which, in the long run, may help to explain the high educational standing and low attrition among W.M.S. missionaries in Japan who surface as the Society's "aristocracy of labour." 
For late-Victorian single women, however, middle-class status was no guarantee of a secure future. Although the minority of W.M.S. missionaries from wealthy backgrounds did not pursue a career as a means of self-support and an economic necessity, for most W.M.S. recruits, like the British middle-class women described by Deborah Gorham, "the role of sheltered flowers, or ornaments in the household, was unattainable." 37 The meagre salary of a minister or teacher could not be stretched to support several unmarried daughters who remained at home. As Martha Vicinus suggests, after the death of their fathers, "these daughters could expect little in the way of an income...and so had the most to gain from the new educational and job opportunities." 38 By the late nineteenth century, in Canada as in Britain, higher education and employment became increasingly necessary and desirable for single urban middle-class and rural women whose families could no longer support them because of economic distress. ${ }^{39}$ Consequently, many W.M.S. missionaries and their parents appear to have sacrificed to obtain the best education available as an entrée to a career.

In 1881, when the W.M.S. began recruiting women missionaries, there were few women university graduates to conscript because of the limited opportunities for Canadian women to attend universities in their own country. In 1872, Mount Allison University in Sackville, New Brunswick, and Queen's University in Kingston, Ontario, opened their doors to women, and in 1875 the first woman to graduate from any university in the British Empire received her B.Sc. from Mount Allison. ${ }^{40}$ In 1877, Victoria University, then in Cobourg, Ontario, admitted women for the first time. ${ }^{41}$ But equal educational opportunities for women gained support very slowly. Literature, art, and music were endorsed as disciplines suitable for women, but there was strong resistance to permitting women to attend medical and law schools. By 1900, however, women comprised 10\% of the university population. Most Canadian universities accepted women applicants on an equal status with men and, in theory at least, women's presence on Canadian university campuses was restricted only by academic standards or family finances. ${ }^{42}$

It is noteworthy that Maritime women were overrepresented among the W.M.S. missionaries who had attended university. While $20 \%$ of all W.M.S. missionaries were raised in the Maritimes, $38 \%$ of the university-educated missionaries were Maritimers. One possible explanation for the disproportionate number of Maritime university graduates may derive from the early Maritime interest in women's university education and the strong presence of Mount Allison as both a university and a ladies' college. Predictably, most of the Maritimers had graduated from Mount Allison, while the majority of Ontarioborn women chose the Methodist Victoria University which moved in 1892 to Toronto. ${ }^{43}$ Other recruits graduated from the University of Toronto, McGill, and, after 1900, the University of Manitoba. Queen's, a Presbyterian-supported university, and McMaster, a Baptist institution, graduated just one W.M.S. missionary each, but many of their women students made their way into Presbyterian and Baptist missionary forces. ${ }^{44}$ Ironically, the increased accessibility 
of university education for women was not reflected consistently in the educational standing of the W.M.S. missionaries. Of the eighteen women born before 1871 and for whom adequate educational data were available, $22 \%$ had attended university while, in apparent conformity with the growing access to university education for Victorian women, $40 \%$ (30) of the 74 women born between 1872 and 1885 had earned a degree. But, only $25 \%$ of the 90 women born between 1886 and 1900 and who, presumably, had the greatest educational advantages and options, had attended university. This suggests, among other things, that after 1900 alternate career opportunities may have been available to more university-trained women and that mission work had become a less-appealing choice.

Like other women of their generation in North America and Britain, once at university, the W.M.S. missionaries tended to follow traditional patterns of study. Few departed from the conventional arts courses which would prepare them for a career as a teacher and which were recommended by university administrators as a background for missionary work. ${ }^{45}$ Among the exceptions, Olive Markland graduated in 1909 from Victoria in honours philosophy, and in 1921 Christina Sturdy enrolled for a year in divinity at Victoria even though she had no prospect at that time of ordination. ${ }^{46}$ Most others graduated with degrees in English or modern languages and, after about 1900 , home economics. Yet, no matter what disciplines and courses the women selected, the university experience and living away from home, as the majority did, exposed them to influences which changed their perceptions of themselves and their aspirations, a transformation which itself was a critical component of the W.M.S. educational process. ${ }^{47}$ As Carol Bacchi has argued, a university education sparked in the Canadian suffragists "an activist frame of mind" because "the spirit of social reform infected the class" room." 48 And even if the curriculum failed to prick the women's middle-class consciences, there was a proliferation of voluntary philanthropic societies on the campus to stimulate their social activism. For one W.M.S. recruit, her years at Victoria and her membership in the Sudent Volunteer Movement, an aggressive organization designed to enlist missionaries, "gradually impressed upon me that perhaps God was asking this of me, even the offering of myself as a living sacrifice." 49

Some contemporary accounts, however, suggest that women university students, especially those living in campus residences, did not always take their work very seriously and that they were not only a privileged, but a pampered and self-indulgent, even frivolous, circle. In her diary, Kathleen Cowan, a student at Victoria University from 1907 until 1910 and a close friend of several future W.M.S. missionaries, recounted to the last detail the daily routine of a small-town girl away from home for the first time and living in Annesley Hall, the women's residence at Victoria. Many of her associates studied only when absolutely necessary and spent their time (and lots of money) in the stores and tea-shops along Toronto's Yonge Street. Apparently, they ironed their elaborate dresses and curled their hair more than they studied Plato or Shakespeare. ${ }^{50}$ But Cowan's 
diary also indicates that if universities of the time adopted a more vigorous role in loco parentis than they now exercise, the university was a less restrictive environment than the family, and the judicious management of time and finances and the mastery of personal relationships fell to the individual.

The W.M.S.'s Board of Managers recognized the value of the total university experience as essential preparation for the "culture shock" of the mission field. At university, the recruits had shown themselves capable of accepting at least some responsibility for their own actions. Furthermore, a B.A. was interpreted as a reliable indicator of general aptitude and, specifically, of the proficiency to leam the difficult Japanese or Chinese languages required to discharge W.M.S. overseas duties. Hence, university education became the yardstick by which the Board determined who was best suited for the coveted foreign postings. As a consequence, $31 \%$ (52 of 165$)$ of the women who became foreign missionaries had university degrees, while fewer than $8 \%$ (11 of 140 ) of home missionaries had attended a university. This disparity may have contributed to the high turnover among home missionaries who had even more problems than overseas missionaries adjusting to their unfamiliar environment and work. Whether the result of personal dissatisfaction with their work and living conditions or because of less decisive career goals, $51 \%$ of home missionaries, in particular the women posted among native peoples in northern British Columbia, an area with even fewer of such niceties of civilization as running water, indoor plumbing, central heating, and cheap servants than Japan or West China, worked for the Society for five years or less.

In 1891, with the opening of its West China mission, the Society began to recruit both nurses and doctors to forge a chain of medical mission stations across the province. Nurses were also hired to staff Methodist hospitals at Port Simpson in northern British Columbia and at Lamont, Alberta. Approximately $7 \%$ of all W.M.S. missionaries and $15 \%$ of the 84 women of the West China mission were trained nurses. Until the late nineteenth century, nursing had not been regarded as an appropriatc career for well-bred women. Nurses had tended to be women whose only other options to support themselves were domestic service, factory work, or prostitution. The revolution in nursing and hospital administration brought about by Florence Nightingale and her disciples after 1870 made nursing an occupation for respectable women. In 1874, the first successful professional nurses' training school in Canada was established in St. Catharines, Ontario. ${ }^{51}$ In the following years, other nursing schools sprang up in its wake, usually in connection with large urban hospitals which needed a secure supply of cheap labour. Gradually nursing emerged as a "new bread-winning occupation," offering adequate wages and status for single middle-class women. 52 In 1900 , in a volume prepared for distribution at the Paris Industrial Exhibition, the National Council of Women recognized nursing, along with teaching and medicine, as one of the few professions open to women in Canada. ${ }^{53}$ After the turn of the century, with the increase in voluntary hospitalization among the middle classes, the 
nursing profession in Canada underwent a rapid expansion from 280 student and graduate nurses in 1901 to 5,600 in 1911 and 30,510 by $19300^{54}$

Several W.M.S. missionaries both trained and worked as graduate nurses at prestigious nursing schools in the United States. Fannie Forrest (born 1874) of Dundas, Ontario, graduated from Boston University Hospital; another smalltown woman, Caroline Wellwood from Wingham, Ontario, also born in 1874, trained in Washington, D.C., while Martha Barnett of Ottawa and Violetta Shuttleworth of Rosseau, Ontario, did postgraduate work at New York City's famed Bellevue Hospital. Some, like Mary Assom of Canmore, Alberta, who attended the School of Nursing at the Ensworth Deaconess Hospital in St. Joseph, Missouri, remained in the United States to work, ${ }^{55}$ perhaps because, as one Canadian hospital administrator recalled, "The American schools offered far greater attractions, and...gave many clever, ambitious women an outlet for their abilities and numbers of them assumed leadership in the rising profession." 56 Consequently, like the university graduates, by the time they joined the W.M.S. ranks, professionally trained nurses too had severed many of the connections which bound them to their families, establishing a degree of independence and autonomy unfamiliar to most of their contemporaries who were still accountable to fathers and husbands. 57

Between 1891 and 1925, the W.M.S. also hired nine women doctors to staff the West China mission stations. Unlike the nurses, only one doctor, Maude Killam, left Canada to receive her medical training. Because the most vigorous stage of the battle for women's entrance to Canadian medical schools had already been waged before the W.M.S. began to enlist its medical force, Killam, a Nova Scotian, might, had she wished, have attended Dalhousie University Medical School (which opened its doors to women in the early 1890 s) or several other medical schools in central Canada. But, presumably because her family could afford it, and because of its excellent reputation, she chose the Women's Medical College at the New York Infirmary. ${ }^{58}$ Retta Gifford (Kilborn) graduated in 1891 from the Woman's Medical College in Toronto, as did Anna Henry in 1898, Mabel Cassidy in 1902, and Olive Rea in 1903. May Austin and Florence O'Donnell, both natives of Halifax, graduated from Dalhousie Medical College shortly after 1900 . For at least two of the doctors, medicine was not their first career, although it may have been their ultimate goal. For example, Lily Snider (M.D., Toronto, 1918) taught for three years after she received her B.A. in 1913, and Ada Speers of Brandon, Manitoba, taught for seven years before she entered medical school. Speers, whose father died when she was thirteen, used her savings from teaching to finance her medical training. ${ }^{59}$ Her case exemplifies "the marginality of [middle-class] status" among W.M.S. missionaries. 60

While most W.M.S. missionaries were equipped for the usual female careers as teachers, nurses, or even doctors, some recruits, because of ability, financial constraints, family and home obligations, or personal preference, prepared for the future in less academic ways. About $4 \%$ of all the missionaries attended a business college and, as W.M.S. operations, especially in foreign fields, became 
more complex, the Board of Managers acknowledged the need for more women whose backgrounds encompassed business, accounting, and stenographic skills. Women with musical training, too, were preferred by the Society because musical instruction was an inducement to upper-class Japanese to enrol their daughters in the exclusive girls' schools which the W.M.S. operated in Japan. In addition, music was essential to the success of the evangelical meetings which the Society sponsored. While only four or five women were graduates of a conservatory of music, many others cited some musical expertise in their applications. One in four of the women appointed to Japan had received some musical instruction, privately, as part of the curriculum at a ladies' college or as a student at the Toronto or Halifax Conservatory of Music. Olive Lindsay, who went to Japan in 1912 and who eventually became an ordained minister, not untypically had one year of vocal instruction, a year of violin, and several years of piano to her credit. $^{61}$ The emphasis the Society placed on their missionaries' musical accomplishments and, to a lesser degree, the artistic diversions such as oil or china painting which the recruits enumerated in their applications suggests that many of the women, like the daughters of British Victorian middle-class families, were still "expected to adorn the household with their skills in music, painting and fancy needlework." ${ }^{62}$ The Board of Managers, composed of equally well-bred women, took all these talents into consideration when evaluating the applications.

The Board, however, regarded relevant work experience as a more practical element in the preparation of its missionaries. After their formal education or professional training was completed and before they made their pledge to become missionaries, at least three-fifths $(61 \%)$ of all the future W.M.S. workers had already been employed outside the home. Moreover, because the Board of Managers rejected women younger than twenty-five, many candidates had extensive work experience when they applied to the Society. Some, like Martha Cartmell, the first W.M.S. missionary sent to Japan in 1882, came to missionary work in their mid-thirties as an alternative to other well-established careers, in her case as a school teacher. Most recruits, especially the university graduates, were in their late twenties. Their age suggests that many women planned carefully for their careers, grooming themselves expressly for missionary work through suitable employment as teachers and medical personnel. The 143 women for whom data were available had worked an average of 4.4 years, long enough to ensure that their self-reliance, which for many had been first established at a university, normal, or nursing school, became a fact of life. As wage-earners, then, even before they joined the Society, many W.M.S. hopefuls were among those independent, self-supporting single women who, to cite one prominent Victorian medical authority, had established for themselves "a sphere of usefulness and happiness second only to that of happily married women."63

In particular, many of them had carved out their niche in the teaching profession where, by the 1870 s, women outnumbered their male counterparts in spite of the unmistakable discrepancies in salaries and opportunities between male and female teachers. ${ }^{64}$ More than one in three (123) of all W.M.S. 
missionaries had attended a provincial normal school, either directly after high school or after university, to acquire one of the wide array of teaching certificates available. Another sixteen were hired as teachers without normal school credentials. In all, almost half the W.M.S. missionaries had teaching experience- 125 as public school teachers, 4 as high school teachers, and 8 as instructors at private schools. Sixty-three per cent of the missionaries in Japan and $40 \%$ of the China hands were teachers before joining the Society. But, reflecting their lower educational rank and the higher demand for teachers overseas, just over one in four of W.M.S. home missionaries (29\%) had ever taught. To the Board of Managers, teaching experience may not have seemed an advantage in Port Simpson where sewing on buttons, combing hair, gardening, and disciplining unruly native children were the order of the day and where the government was responsible for a minimum education for the native population.

Two-thirds of the trained nurses had some work experience before they were recruited, but perhaps because of limited opportunities for female physicians in Canada, only three of the nine doctors appear to have practised for even a few months before going to China. Five per cent of the candidates (16) had been employed in business, while 4\% (13) had engaged in social work or were trained and served as deaconesses. Although the majority of the W.M.S. applicants had held poorly paid but "socially acceptable" jobs, ${ }^{65}$ which "were probably a condition of female employment in the first place," $" 66$ a few had, in fact, worked their way into positions of respect and authority, albeit usually in the field of education. Elizabeth AIcorn, who spent many years in Japan, had previously been the head of the art department at Mount Allison Ladies' College; her co-worker in Japan, Myra Veazey, a graduate of the University of New Brunswick, taught privately in Maine and at the Cookman Institute for Negro Students in Jacksonville, Florida, one of the first black colleges operated by the Methodist Church of the United States. ${ }^{67}$ Esther Ryan, also stationed in Japan, had been principal of Shawville Academy in Quebec before she joined the W.M.S. in 1913. Annie MacLean was the principal of two elementary schools, still rare for a woman even in the 1920s, while Muriel Hockey had been the assistant principal of the Methodist Training School in $1912 .{ }^{68}$ Positions like these provided the women with a unique chance to assert themselves, often in exclusively female communities, and accustomed them to independent decision. making. These women subsequently were given responsible administrative appointments in the field where they could utilize their exceptional skills.

There is, however, no information to document the work experience for almost $40 \%$ of the women, probably because they had no paid position beyond their households. Some of the applicants who had remained at home were very proud of their ability to work hard and enumerated their domestic accomplish. ments in their applications. Rural aspirants who may have had limited opportunities for any suitable employment opportunities in the work-force boasted of their physical stamina and the responsibility of keeping house for a widowed parent or orphaned brothers and sisters. As young women raised in a strong 
Christian tradition which "implied obedience to older kin," the care and custody of the family were fundamental aspects of their lives. ${ }^{69}$ The members of the Board of Managers who seemed sympathetic to these family obligations sanctioned some domestic experience as useful training for work among recent immigrants to Canada or for managing boarding schools among the Indians but dismissed it as inconsequential, compared to an academic or medical background, for work in the Orient.

Until 1895 , if the candidate had a satisfactory medical report and the Board of Managers approved her application and testimonials, she was ready to be assigned to the field. But after 1895, another hurdle was placed in the paths of the missionary hopefuls in the form of attendance, for at least a term, at the newly opened National Methodist Training School located at 28 McGill Street, Toronto, to train Methodist women as deaconesses. ${ }^{70}$ In some cases, to hasten the candidate's departure for the mission field, attendance at Training School might be waived if she had a satisfactory religious background or had already attended the Moody Bible Institute or Folts Institute, a professional training school for missionaries in Herkimer, New York. ${ }^{71}$ But from 1895 to 1925, at least one-third of all W.M.S. missionaries entered the Training School as the final phase of their increasingly rigorous professional training.

The courses required of W.M.S. candidates at the Training School were designed to repair a multiplicity of defects in both religious knowledge and character. In one unusual instance, a young woman whose credentials were "very satisfactory as far as her Christian character and ability [were] concerned" was referred to the Training School because of "her lack of neatness... a matter of great importance in any one who goes to work among the Indians." A term at the Training School was recommended to improve her personal appearance and to give the Board of Managers "sufficient time to form a definite opinion in the matter." Training School proved to be the suitable corrective; the woman was reformed, hired, and remained with the W.M.S. serving in home missions for the next thirty years. 73

The spartan and almost cloistered life of the Training School was a harsh introduction to missionary life, especially for women who had just spent three or four years at college, but few prospective missionaries dropped out. Residents of the Home paid for room, board, fuel and light, and they "assume[d] cheerfully [a] share of the general housework." They fumished their own blankets, towels and soap, kitchen aprons, heavy underflannels (with sleeves), overshoes, leggings, and "gossamer and umbrellas, as the work may require one to be outdoors in all weather." 74 Social life at the Training School was equally regimented. Callers could be received only on Friday evening; Sunday and one other evening might be spent outside the home without special consent. ${ }^{75}$

The curriculum, designed for deaconesses and other Methodist workers, initially consisted of courses focusing on the interpretation of the Bible, church history, and the study of Christian doctrines with special emphasis on Wesley's sermons. Practical instruction was given in kitchen gardening, that is, raising 
vegetables for consumption by the individual family, sewing, cooking, and other skills which a deaconess or missionary needed to improve the material state of her charges at home or abroad. Students also attended lectures on temperance, missionary work, and emergency medical procedures. Reflecting the mood of the period, the women participated in physical exercise and drills, which they, in turn, passed on to their own students. ${ }^{76}$ Twenty years after the Training School opened, the course for missionaries had expanded to fill seven months and included kindergarten instruction, household science, the history and methods of missions, and the constitution and work of the W.M.S. ${ }^{77}$ Again in the 1920s, with the increased emphasis on the social gospel and the Methodist Church's "call for a complete social reconstruction," 78 the curriculum expanded to incorporate such topics as "The Social Gospel of the New Testament and its Application to Modern Life" and "The Social Programme of Canadian Methodism," a theme which covered child welfare and the "spiritual value of Golden Rule Application."79 In the later years, especially, attendance at the Training School was a constructive experience. The women were exposed to new ideas and methodologies which they could apply to their own missionary careers. Just as importantly, they became well acquainted with the women who would become their co-workers and surrogate family in the mission field.

But mature, well-trained, and eager as Martha Cartmell and her 300 successors were, even in the 1920 s, women entering W.M.S. missionary ranks with all the advantages of others' experience behind them discovered, to their discouragement, that their intensive education and professional backgrounds had not prepared them for the adversity and frustration which threatened their physical, emotional, and spiritual well-being. Facility at Latin or French did not necessarily translate into the mastery of Chinese or Japanese; even many university-educated overseas missionaries never became fluent enough in the language of their constituents to feel altogether confident about their teaching and evangelizing assignments. Nonetheless, the Board of Managers maintained that a liberal education gave their employees far more than the potential for competence with languages. In a pamphlet published about 1915, the W.M.S. pointed out that a college education and its extracurricular activities provided the

opportunity to enlarge the vision of the candidate; to hear and meet distinguished persons; to listen to the best in dramatic art and music as well as in literature, history and science; to appreciate pictures; to use great libraries - in short, to widen her experiences that she may become a citizen of the world. ${ }^{80}$

Obviously, the Society valued the self-confidence, the independence, the management and administrative skills, and the curiosity, questioning, and social awareness that many W.M.S. employees first acquired during their university days as among the criteria essential for success and longevity in a missionary career. Moreover, based on its perception of the missionary paradigm, the 
W.M.S. Board of Managers made the calculated decision that its most educated, middle-class recruits should be the guarantors of the Society's most successful and prestigious mission field in Japan. It was a conclusion which statistics about career length support.

It does not seem coincidental, for example, that the twenty-eight university graduates in the Japan mission field had careers averaging 27.1 years compared to 18 years for the women with no university background. The pattern is repeated for West China and for home missions, suggesting that W.M.S. university graduates were, in fact, more committed to the goal of a professional career as single women than their less educated colleagues. Moreover, this nucleus of dedicated career missionaries in Japan helps to explain why the drive for professionalization with the concomitant employee benefits and increased autonomy in the mission field was launched by the Japan Mission Council's university women. But conversely, if certain aspects of home missionary work were less productive than the Board of Managers anticipated, it may be ascribed to the excessive attrition among home missionaries, the least qualified W.M.S. personnel among whom university women were a rarity. More B.A.'s to "wip[e] up the floor" ${ }^{281}$ and shoulder the less glamorous burden of home missions might, in the long run, have strengthened and stabilized the W.M.S. missionary operations in Canada, which suffered perennially from a high tumover and a distinct lack of professional commitment among the workers.

As an agency to Christianize and reform Canada and the world, the Methodist W.M.S. did not realize its high evangelistic expectations; but, for a select group of women in late nineteenth and early twentieth-century Canada, missionary work had offered a challenging career alternative to marriage, spinsterhood, or employment opportunities checked by too close an attachment to the affairs of men. The women who persisted as W.M.S. career missionaries were satisfied, even enthusiastic and elated, with their freedom and the unique challenges which their work presented. They were especially proud of their ability to adapt to the most unusual circumstances. Their exceptional education and training had liberated them from the "gilded bower of matrimony," equipping them instead for a rewarding career of professional social activism in the name of Christ. From this perspective, the Society's own assumption that "among 'Progressive Women' the educated, cultured missionary holds first place," seems fully justified. ${ }^{82}$

\section{NOTES}

1. Annual Report of the W.M.S., 1886-87, (hereinafter cited as ARWMS), 125.

2. Ibid., 126.

3. Michael Gauvreau, "The Taming of History: Reflections on the Canadian Methodist Encounter with Biblical Criticism, 1830-1900," Canadian Historical Review LXV (Sept. 1984): 317. Bernard Semmel in The Methodist Revolution (New York: Basic Books, 1973), 17, offers the following explanation of "experimental religion": 
By a profound emotional and mystical experience more accessible to the humble and unsophisticated than to their better situated or better educated fellows, large numbers of men might attain the certainty-the Assurance-that though they had been sinners, their sins had been forgiven and they had been accepted by God and could by their own efforts, reinforced by the fratemal spirit of the societies, find ultimate sanctification, that is, Salvation.

4. ARWMS, 1886-87, 126.

5. Ibid.

6. ARWMS, 1895-96, 125 .

7. ARWMS, 1886-87, 126.

8. Ibid., 125.

9. E.S. Strachan, "Woman's Missionary Societies," Canadian Methodist Magazine XVI (July-Dec. 1882): 228.

10. Anne C. Legendre, "The Baptist Contribution to Nineteenth Century Education for Women: An Examination of Moulton College and McMaster University" (M.A., Mc. Master University, 1981), 59-60.

11. Carol Bacchi, Liberation Deferred? (Toronto: University of Toronto Press, 1983), 19. 12. Rev. C.H. Payne, "Women and Their Work in Methodism,"The Canadian Methodist Magazine L (June "Dec. 1899): 500.

13. The Christian Guardian, 25 Jan. 1888.

14. See Ramsay Cook. The Regenerators: Social Criticism in Late Victorian English Canada (Toronto: University of Toronto Press, 1985), ch. 5 for an extended discussion of the ideas of Benjamin Austin.

15. B.F. Austin, ed., Woman: Her Character, Cullure and Calling (Brantrord: The Book and Bible House, 1890), 35.

16. Ibid., 33.

17. W. Withrow, "Higher Education of Women," in Woman, ed. B.F. Austin, 330.

18. United Church Archives (UCA), Biographical file of Margaret Armstrong.

19. Alison Prentice, Paula Bourne, Gail Cuthbert Brandt, Beth Light, Wendy Mitchinson, and Naomi Black, Canadian Women: A History (Toronto: Harcourt Brace Jovanovich, 1988), 156; Robert M. Stamp, The Schools of Ontario, 1876-1976 (Toronto: University of Toronto Press, 1976), 7.

20. Rev. Edwin W. Edwards, The History of Alma College (1927), 8.

21. Marion Royce, "Methodism and the Education of Women in Nineteenth Century Ontario," Atlantis III, 2 (Spring 1978): 142.

22. M. Royce, Landmarks in the Victorian Education of Young Ladies under Methodist Church Auspices (Toronto: Ontario Institute for Studies in Education, 1977), 3-24.

23. Edwards, Alma College, 23.

24. Public Archives of Ontario, Ontario Ladies' College Papers, Education Department Papers, School Reports, 1850-1890, Box 1, Ontario Ladies' College, Whitby, Ontario, $1879-1880,16$.

25. Ibid., 24.

26. Report of the Massey Foundation Commission on the Secondary Schools and Colleges of the Methodist Church of Canada 1921 (Toronio: The Massey Foundation, 1921), 65.

27. Ontario Ladies College, 20.

28. Alma College Centennial Book 1877-1977 (S1. Thomas, 1977), 27.

29. Martha Vicinus, "Distance and Desire: English Boarding-School Friendships," in The Lesbian Issue: Essays from Signs, ed. Estelle B. Freedman, Barbara C. Gelpo, Susan L. Johnson, and Kathleen Weston (Chicago: The University of Chicago Press, 1985), 47. 
30. Austin, Woman, 443.

31. M.C. Urquhart and K. Buckley, eds., Historical Statistics of Canada (Toronto: The Macmillan Company of Canada, 1965), 86.

32. John Reid, "The Education of Women at Mount Allison, 1854-1914," Acadiensis XII (Spring 1983): 24.

33. Ibid.

34. Daniel Kubat and David Thomton, A Statistical Profile of Canadian Society (Toronto: McGraw-Hill Ryerson Ltd., 1974), 131.

35. William Magney, "The Methodist Church and the National Gospel, 1884-1914," The Bulletin 20 (1968): 3; Neil A. Semple, "The Impact of Urbanization on the Methodist Church in Central Canada, 1854-1884" (Ph.D. diss., University of Toronto, 1979), 31.

36. Unless the parent was a minister, it was impossible to determine the occupations of parents of those women who were born after 1891 and whose names did not appear on the available census records. Even a search of the 1891 census failed to bring worthwhile results. On the other hand, using Methodist Church records, it was possible to locate all fathers who were ministers.

37. Deborah Gorham, The Victorian Girl and the Feminine Ideal (London: Croom Helm, 1982), 11 .

38. Martha Vicinus, Independen Women: Work and Community for Single Women, 1850.1920 (London: Virago Press, 1985), 7.

39. Marjoric Cohen, Women's Work, Markets, and Economic Development in NineteenthCentury Ontario (Toronto: University of Toronto Press, 1988), 124-27.

40. Anne R. Ford, A Path Not Strewn with Roses: One Hundred Years of Women at the University of Toronto, 1884 -1984 (Toronto: University of Toronto Press, 1985), 5.

41. Bacchi, Liberation Deferred?, 19.

42. Prentice et al, Canadian Women: A History, 158-62.

43. C.B. Sissons, History of Victoria University (Toronto: University of 'Toronto Press, 1952), 197.

44. Ten women, toth married and single, who served at the Canadian Baptist mission in India had attended McMaster University and eight had attended Acadia University in Wolfville, Nova Scotia, another Baptist college. See Canadian Baptist Archives, McMaster University, A Sketch of the Origin and Development of our Mission Stations in India (Toronto: Canadian Baptist Foreign Mission Board, 1922), 187.97.

45. See UCA, Margaret Addison, "Shaping a College Course with a View to Mission Work," Pamphlet, W.M.S., c. 1918.

46. UCA, Biographical files of O. Markland and C. Sturdy; W.M.S. Notebooks.

47. Roberta Frankfort, Collegiate Women: Domesticity and Career in Turn-of the-Century America (New York: New York University Press, 1977), 55.

48. Bacchi, Liberation Deferred?, 21.

49. "Testimony of an Anonymous W.M.S. Recruit," Missionary Outlook, Dec. 1904, 282.

50. Kathleen Cowan, It's Late and All the Girls Have Gone: An Annesley Diary, 1907-1910, ed. Aida Farrog (Toronto: Childe Thursday, 1984).

51. Judie Coburn, "'I See and am Silent': A Short History of Nursing in Ontario," in Women at Work, Ontario 1850-1930 (Toronto: Canadian Women's Educational Press, 1974), 135-36.

52. "The Life of a Nurse," The Globe, 8 Oct. 1886, in Sara Jeannelle Duncan, Selected Journalism, ed. Thomas E. Tausky (Ottawa: Tecumseh Press, 1978), 29.

53. Women of Canada: Their Life and Work (The National Council of Women of Canada, 1900: reprinted 1975), 58. 
54. Coburn, "'I See and am Silent"", 163.

55. UCA, Biographical files of Forrest, Wellwood, Barnett, Shuttleworth, and Assom.

56. C.K. Clarke, A History of the Toronto General Hospital (Toronto: William Briggs, 1913), 94.

57. Rosemary Ball, "A Perfect Farmer's Wife," Canada 3 (Dec. 1975): 2-21.

58. Virginia G. Drachman, "Female Solidarity and Professional Success: The Dilemma of Women Doctors in Late Nineteenth-Century America," Journal of Social History (Summer 1982): 608.

59. UCA, Biographical file of Ada Speers; E.M. Speers Meuser autobiography in papers of E.M. Speers Meuser.

60. Veronica Strong Boag, "Feminism Constrained," in A Not Unreasonable Claim, ed. Linda Kealey (Toronto: Women's Educational Press, 1979), 119.

61. UCA, Biographical files and W.M.S. notebooks.

62. Gorham, The Victorian Girl, 27.

63. Eliza Mosher, M.D., "The Health of American Women," in Woman, ed. B.F. Austin, 242.

64. Women at Work, 177; M. Danylewycz, B. Light, and A. Prentice, "The Evolution of the Sexual Division of Labour in Teaching: A Nineteenth-Century Ontario and Quebec Case Study," Histoire Sociale/Social History XVI (May 1983): 89; M. Danylewycz and A. Prentice, "Teachers' Work: Changing Patterns and Perceptions in the Emerging School Systems of Nineteenth-and Early Twentieth-Century Central Canada,"Labour/Le Travail 17 (Spring 1986): 79.

65. Carl Degler, At Odds: Women and the Family in America from the Revolution to the Present (New York: Oxford University Press, 1980), 380.

66. Alison Prentice, "The Feminization of Teaching," in The Neglected Majority, ed. S.M. Trofimenkoff and A. Prentice (Toronto: McClelland and Stewart, 1977), 56.

67. Mary McLeod Bethune, "How the Bethune-Cookman College Campus Started," excerpted from "Faith that Moved a Dump Heap," in Who: The Magazine about People 1 (June 1941): 31 35, 54; in Women's America: Refocusing the Past, ed. Linda K. Kerber and Jane DeHart Mathews (New York: 1982), 260-62.

68. UCA, Biographical files, and Manuscript Census of Canada, 1861-1881.

69. Beth Light and Joy Parr, eds., Canadian Women on the Move 1867-1920 (Toronto: New Hogtown Press and The Ontario Institute for Studies in Education, 1983), 50.

70. Ibid., and J. Thomas, "Servants of the Church: Canadian Methodist Deaconess Work," Canadian Historical Review LXV (Sept. 1984): 378.

71. Patricia Hill, The World Their Household (Ann Arbor: University of Michigan Press, 1985), 126.

72. UCA, Methodist Church of Canada, Alexander Sutherland Papers, Box 6, File 12, Sutherland to E.S. Strachan, July 5, 1894.

73. UCA, Biographical file of H. Paul.

74. Fifth Annual Report of the Toronto Deaconess Home and Training School of the Methodist Church of Canada, 1899, 8.

75. Ibid.

76. Fourth Annual Report of the Toronto Deaconess Home and Training School of the Methodist Church of Canada, 1897-98, 11.

77. Bulletin of the National Training School, 1916, 30.

78. Richard Allen, "The Social Gospel and the Reform Tradition in Canada, 1890-1928,"

Canadian Historical Review XLIX (Dec. 1968): 392.

79. National Training School Bulletin, 1922-23, 21-23. 
80. UCA, Addison, "Shaping a College Course," Pamphlet, W.M.S., 6.

81. Missionary Outlook, Nov. 1911, 256.

82. Ibid., Sept.- Oct. 1921, 191. 